\title{
The Effect of Half-year Education to Cultivate Dialogical Thinking Ability for Students in the Electrical Engineering Majors
}

\author{
Mika Nakano Member (Fukuoka Institute of Technology) \\ Kenji Takahara Member (Fukuoka Institute of Technology) \\ Toshinori Kajiwara Member (Fukuoka Institute of Technology)
}

Keywords : engineering education, communication, curriculum, dialogical thinking, argument

This paper describes the effect of half-year education to cultivate dialogical thinking ability for students in the electrical engineering majors. It is based on the case of Fukuoka Institute of Technology which started new courses for communication skills in 2007. A series of communication education from the freshman to the third year is designed, based on the Process of attitude change of students through dialogue. The first introductory class of all is "Communication Theory I". The purpose of this half-year course was to develop self-awareness and to improve interpersonal relationship through dialog. In the classes, students continually learn dialogue and cooperation through various styles of discussion and debate. In this course, students are expected to acquire skills to construct their arguments about the given issues and to evaluate others' opinion each other.

The eesencial point of instructional program can be summarized as the following five constituents: preparation, group size, evaluation, theme, standpoint (Fig. 1). The first "preparation" indicates the time to rely on outside information and to organize the contents of speech. During the early stage of learning, students are easy to make a speech extemporaneously about daily-life matter without preparation. After they become used to stating own idea to others, preparation for higher-level to get information and data is effectively used as a means of deeping understating of the origianal idea. The second "group size" needs to be adapted to the contents of learning. More members participate in discussion, higher skills are required to form a conclusion. The third is "evaluation". Evaluation is neccesary to chech whether knowledge

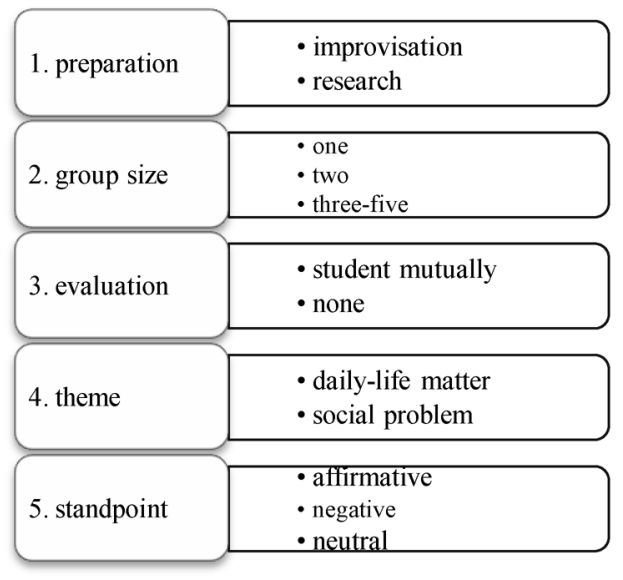

Fig. 1. Constituents of debate program

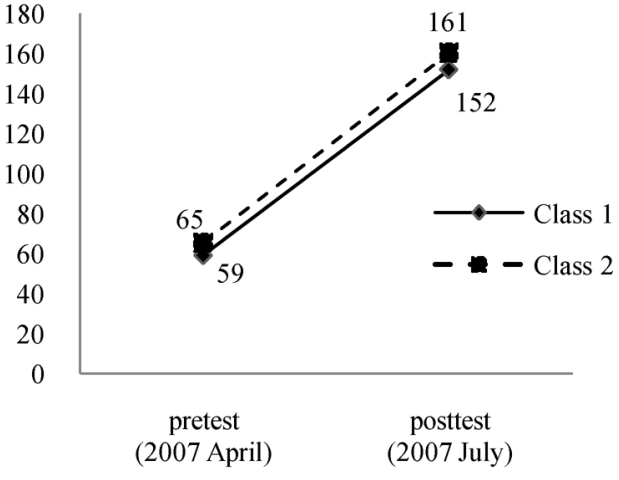

Fig. 2. Change of speech words

and skills are learned or not. Mutural evaluation among students with the same level help them in an objective, straightforward manner. The forth is "theme". How to discuss is related with what to discuss. When teachers focus on students' attitudes for discussion with others, low-impact theme such as daily-life matter is better. environment or attitude, the theme should be about daily-life matter. When they expect students to carefully examine problems from various angles, on the other hand, social problem is suitable. discussing about social problem is suitable. The fifth is "standpoint". Generally debate has two sides: affirmative and negative. When some students hesitate to decide which side to stand, neutral can be the option. The point is not to force them one side but to construct reason to support the claim.

To clarify the effect of the above educational program, the pretest (April) and the posttest (July) were conducted before and after the course. The result of speech words is shown in Fig. 2. At the pretest, the average of class 1 was $59.5(S D=39.2)$, the class 2 was $65.3(S D=30.3)$. After the course, at the posttest, the average of class 1 was $152.0(S D=79.9)$, the class 2 was $160.5(S D=71.2)$. Comparing with two results at the different time, the average of speech increased three times. Looking at the data individually, no students were found whose speech data was unchanged. From this result, students express more about their ideas after taking the course, adding example, data and so on. This indicates that they know how to make others understood what they want to say using various kinds of explanation.

By repeatedly exchanging opinions with sutdents on a wide range of issues, students became more dialogical to both others and themselves. Their skills and atitudes aquired in this half-year class need to be fosterd in the long term. 


\title{
電気系学生を対象にした対話的思考力育成教育の半年間の効果
}

\author{
正 員 中野 美香* 正 員 高原 健爾* \\ 正 員 梶原 寿了*
}

\section{The Effect of Half-year Education to Cultivate Dialogical Thinking Ability for Students in the Electrical Engineering Majors}

Mika Nakano*, Member, Kenji Takahara*, Member, Toshinori Kajiwara*, Member

This paper describes the effect of curriculum for communication ability, "Communication Theory I", newly started in Fukuoka Institute of Technology in 2007. The purpose of this half-year course was to develop self-awareness and to improve interpersonal relationship through dialog. The program was designed, based on the Process of attitude change of students through dialogue. In the class, students were encouraged to take active role in discussion, constructing one's own argument and refuting others'. Emphasis was also placed on giving the students the opportunity to evaluate other students' discussion. Results showed differences in pre-test-post-test comparisons, confirming that learning environment for discussion could result in conceptual change for students. Further interview analyses and analyses of speech data helped to clarify what was learned through debate.

キーワード : 教育, コミュニケーション, カリキュラム, 対話的思考, 議論

Keywords : education, communication, curriculum, dialogical thinking, argument

\section{1. はじめに}

近年，技術者のコミュニケーション能力をどのように育 成するかについて様々な議論がおこなおれている。福岡工 業大学電気工学科では, 社会的な要請に応えるために ${ }^{(1)}$, 2007 年度入学生からの新カリキュラムで情報処理・コミュ ニケーション科目群が新設され, 必修授業としてコミュニ ケーション教育に特化した講義が開講されることとなっ た (2) (4)。このプログラムの特色は, 対話的思考力の育成方 法として議論力の獲得を最終到達点とし, 3 年間にわたって 段階的に教育をおこなう点にある。各年のカリキュラムの 主眼はそれぞれ，1 年次に「自分の考えを整理し，他者の考 えを評価すること」を， 2 年次には「多様なテーマについて 調査し，プレゼンテーションを行うこと」，3 年次には「英 語でプレゼンテーションをし, 技術者倫理について学ぶこ と」とした。「コミュニケーション能力」と一言にいっても その定義は多種多様であるが，その中でも議論は最も高度 なコミュニケーションの一形態であると考えられている。 ある論題について異なる他者と主張や反論を交わし, 意思 決定をおこなう議論のスキルは，いかような職種であって も社会的日常のコミュニケーションにおいて重要であるだ

\footnotetext{
福岡工業大学工学部電気工学科

干 811-0295 福岡市東区和白東 3-30-1

Dept. of Electrical Eng., Fukuoka Institute of Technology

3-30-1, Wajirohigashi Higashi-ku, Fukuoka 811-0295
}

けでなく, 科学的知識を身につけるのに不可欠である。し かしながら，面と向かって他者と友好な関係を保ちながら 異論を唱えることや, 自分の主張を伝えることは, 大学生 にとって必ずしも容易なことではない。

第一筆者は, 対話教育の専門家として, 一連の電気工学 科のカリキュラム開発に深く関わる機会を得た。工学分野 においてコミュニケーション教育が注目されている近年, 学科のニーズに合わせて教育プログラムを作成する過程で 得られた知見は, 他の教育者・研究者にとっても役立つの ではないかと考えられる。また，今後はコミュニケーショ ン教育をただ実践するだけでなく, その効果を科学的に検 証し知見を蓄積することが教育機関に求められていくであ ろう。そこで本稿では, 福岡工業大学電気工学科における “コミュニケーション論 I” の事例をもとに, 電気系学生を 対象とした対話的思考力教育の導入方法を紹介し, 教育プ ログラムの半年閒の効果を明らかにする。

\section{2. 技術者に必要な対話的思考力をどのように 教育するか}

本章では， 1 年前期科目のコミュニケーション論 $\mathrm{I}$ の授業 について紹介し，コミュニケーション教育の導入および指 導方法に関する知見をまとめる。

〈2・1〉理論的背景 本学科でコミュニケーション教 育のプログラムを作成するにあたって, 電気系学生には抽 
象概念を具体的事象に置き換えて理解するための思考力, およびそれを他者に伝える表現力が不可欠であると考え た。例えば，電気回路では時間領域と周波数領域での解析 を学習するが, 直感的に捉えやすい時間領域の現象を周波 数領域の現象に置き換えて理解するためには，単にフェー ザ法やラプラス変換を学習するだけでは不十分である。そ のため電気系分野での専門知識を獲得するには，学生は数 学的な変換に物理的意味を持たせ, 多角的に思考する必要 がある。このような能力を育成する初めの手段として，議 論の訓練が有効であると判断した。なぜなら, 議論は科学 の基礎である論理操作と定性的理解に必要な思考力と, そ れを表現する能力をバランスよく訓練することができるか らである。授業では，議論をとおして学生にわかりやすい 表現力を身につけさせるだけでなく, 説明を生成する過程 で自分の理解の程度を確認し, 思考方法を改善する機会を 与えることが重要だと考えた。

コミュニケーション能力の育成には段階が必要であると 考えられる。話し方やプレゼンテーションの表面的な技法 だけを教授しても，その技法を駆使するための土台となる 個人の哲学, その裏づけとなる知識や知恵が十分でなけれ ば，役には立たない。本研究者は議論による学生の意識・ 態度変化のプロセスを図 1 のように示した ${ }^{(5)}$ 。議論は自分の 主張を構築し, 相手の主張に反論したり, 相手から反論さ れることを通して, 主張を再構築するものである。そこに は異文化の価值観の気づきがあり，それによって自文化の 気づきが発見される。自他の区別が明らかになったところ で, はじめて対話技術ひいては議論に必要な知識の獲得が 促進され，他者との対話により自己を省みる姿勢を育むこ とができる。反省的自己の形成はいかような場合において も適切なコミュニケーションの成立には不可欠である。

しかし，本邦では学生がこういった思考や表現方法に関 する教育を受ける機会は少なく, 大学生の対人コミュニケ ーション能力の低下が多方面から指摘される中, 大学が学 生と社会の橋渡しをすることが期待されている。一般的に 必修授業でコミュニケーションに関心のない学生に議論を 教授することは困難と考えられているが，3 年間という長期 的なスパンでスキルの熟達化を捉え, それに沿った教育プ ログラムを研究開発することによって, 議論力の育成も可

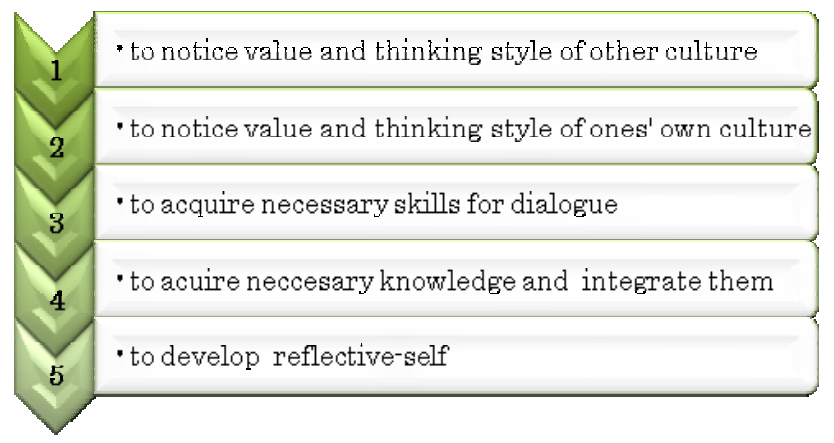

図 1 学生の意識・態度変化のプロセス

Fig. 1. Process of attitude change of students through dialogue.

\section{能になると考えた。}

〈2·2〉授業の概要 “コミュニケーション論 I” は議 論力の礎となる, 他者に開かれた思考や態度, 寸なわち対 話的思考力を身に付けることを目的としている。半年間の 異文化適応期に，学生が議論を通して「大学生としての自 己」と「他者」を発見できるような学習環境づくりを目指 した。そのため, 授業では表面的なコミュニケーションの スキルを教授するだけではなく, 自己を探究し, 他者を尊 重する前提の文化を育む仕掛けや配慮が重要になる。

授業は, 福岡工業大学工学部電気工学科 1 年生, 約 100 を対象におこなった。受講生を 2 クラスに分け, 週 1 コマ, 試験を含めて半期 15 回で完結する。2007 年度の授業は, コ ミュニケーション教育の専門家である第一筆者と, 電気工 学科の専任教員である第二筆者 2 名で, チームティーチン グをおこなった。この他, アドバイザーとして同学科専任 教員の第三筆者と, 大学院生 2 名がティーチング・アシス タントとして授業に参加した。

“コミュニケーション論 I ”の目的として，授業計画には 「社会人になるための素養を身に付け, よりよい大学生活を 過ごすための導入教育をおこなう。コースでの講師や他の 学生との議論を通して, 受講者は自分の社会的位置付けを 探索する」とした。また, 授業目標を達成するために授業 を導入期, 発展期, 応用期の 3 段階に分け, それぞれの目 標を設定した。この段階に合わせて, 試験と試験後の反省 学習の授業を除く 13 回分の講義を 3 期に分け, 次のような 授業をおこなった。第 1 回一第 3 回の導入期では, 授業の 方針や進め方に関して説明し, 自分についての理解を深め るために自己分析させた。第 4 回一第 7 回の発展期は, 考 えを整理するために主張と反論の基礎的技術を身に付け, 論理的思考を育成する論理トレーニングを取り入れた。第 8 回一第 13 回の応用期は, ディベートを用いて議論の実践を すると共に, クラスに自由に議論を交わす風土を根付かせ た。

〈2·3〉指導プログラムの構成 応用期の 6 回分の授 業は, 授業全体で最も重要な位置付けを占める。自分の考 えを整理し，それを他者に伝える論理的な思考法および表 現力を育成するために, 学生の議論スキルの熟達化過程に 基づいたプログラムを作成した。議論の課題を考案するに あたって,「準備」「人数」「評価」「論題」「立場」の 5 要素 を学生の状況に合わせて組み合わせた（図 2)。

「準備」は，その場で課題を示し，取り組ませる即興型と， 1 週間前などあらかじめ課題内容を伝えて準備をさせるリ サーチ型である。論題の難易度にもよるが, 初めからリサ 一チの量が多いと調査型の発表に慣れていない学生にとっ て負担になる。そのため, 議論の練習をこなし, 一通りで きるまでは即興型の方がクラス全体を均一に指導すること ができる。一方で, 議論に必要なスキルが身についた段階 でデータや情報をリサーチして集めることの重要性を教え ると効果的であった。発表では即興型と準備型を組み合わ せ, 最終的には与えられた論題についてその場で考えなが 


\begin{tabular}{|c|c|}
\hline 1. preparation & $\begin{array}{l}\text { - improvisation } \\
\text { - research }\end{array}$ \\
\hline 2. group size & $\begin{array}{l}\text { one } \\
\cdot \text { two } \\
\cdot \text { three-five } \\
\end{array}$ \\
\hline 3. evaluation & $\begin{array}{l}\text { - student mutually } \\
\text { - none }\end{array}$ \\
\hline 4. theme & $\begin{array}{l}\text { - daily-life matter } \\
\text { - social problem }\end{array}$ \\
\hline 5. standpoint & $\begin{array}{l}\text { - affirmative } \\
\text { - negative } \\
\text { - neutral } \\
\end{array}$ \\
\hline
\end{tabular}

図 2 指導プログラムの構成要素

Fig. 2. Constituents of debate program.

ら話せることを目指した。

「人数」は議論をおこなうグループの人数のことで, 考え ることに集中する場合は 1 人, 相互作用について学ぶ場合 は 2 人，多様な意見を出し，議論をおこなうことを目的と する授業では 3 人から 5 人とした。最初から複数人で話す と全員が発言できないことがあるため，クラスが議論に慣 れるまでは 2 人 3 人が望ましい。ただし, 個人の発表時間 を確保して順番を決めることによって，ある程度の人数で あっても全員の意見を発表させることができた。

議論の「評価」は，時期によって他者から評価がある場 合と, ない場合に分けた。他者からのフィードバックがあ る方が改善されや寸いが, 初期段階では慣れることが重要 なため評価がない方が，学習がスムーズにいくことがある。 他者から指摘されて改善することも重要であるが，自分で 自分の課題に気づくことも対話の技術においては重要であ ると考えた。

「論題」については, 誰でも話題をもっている身の周りの テーマから，ある程度，知識が試される社会問題まで幅広 く取り入れた。初期段階は, 誰もが話す内容をすぐに考え 付くような話題を扱う方が，議論のスキルの教授に集中し やすい。一方である程度, 慣れてきた段階で時事問題の論 題を用いることで, 日常生活でのリサーチの必要性を実感 させ，習慣化させる効果が期待できる。

議論の「立場」は，賛成や反対だけでなく，中立の立場 も設けた。これは, 一般的にはディベートでは賛否の二者 で議論をおこなうが，議論に慣れていない場合，どちらか 一方に立場を決めきれない学生が多く見られたためであ る。評価の際には, どの立場であっても, 立場をサポート する理由付けが的確に行われているかを判断基準とした。 ある立場に立って主張する時には, 以下の主張の型（順序） を示し繰り返し徹底させた：(1)主張を述べ, (2)主張のポイ ントを示し，(3)理由を示し，(4)具体例を提示し，(5)結論を 述べる。指導においては, どの主張が正解というわけでは なく，立場を支持する理由が述べられているかどうかを検
表 1 議論の評価指標 ${ }^{(6)}$

Table 1. Evaluation criteria of argument.

\begin{tabular}{|c|c|}
\hline 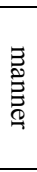 & $\begin{array}{l}\text { 1. voice volume } \\
\text { 2. speed } \\
\text { 3. intonation } \\
\text { 4. emphasis } \\
\text { 5. Eye contact }\end{array}$ \\
\hline $\begin{array}{l}\overrightarrow{\mathrm{d}} \\
\stackrel{\mathrm{W}}{\oplus}\end{array}$ & $\begin{array}{l}\text { 1. claim } \\
\text { 2. reason } \\
\text { 3. example and data } \\
\text { 4. organization } \\
\text { 5. interested }\end{array}$ \\
\hline
\end{tabular}

討し, 推論過程を吟味することに重点を置いた。また, 聴 衆分析に焦点を当て, 理由の妥当性は聴衆によって判断さ れることを学生に理解させた。

$\langle 2 \cdot 4\rangle$ 議論の相互評価の基準 本節では議論を学生 にどのように相互評価させるか，その基準を紹介する。授 業では, 発表者以外の学生は発表者の主張の論点をまとめ るとともに相互評価をおこなった。評価の内容は, 議論の 主要な構成要素である大きく「議論の伝え方 (manner)」「議 論の内容 (matter)」に分けられ，それぞれ５つの下位項目を 設定した（表 1)。議論の伝え方に関する評価項目は，(1)声 の大きさ，(2)話寸速さ，(3)声の高低，(4)間の使い方，(5) イコンタクト, の 5 つである。議論の内容に関する評価項 目は, (1)ポイントの明確さ, (2)説明のわかりや寸さ, (3)例 やデータの適切さ, (4)興味深さ, (5)構成のまとまり,の 5 つである。誰かの発表を評価する時には，学生にそれぞれ の項目に対して 5 段階で採点させ, 改善点をコメントさせ た。

学生は，授業で用いた評価指標のみならず学生同士で評 価すること自体に慣れておらず, 相互評価の導入直後は被 評価者全員に 5 点をつけるなど高評価が多く見られた。そ のため, 基本を 3 点とし, そこから自分の判断で加減する ことと, コメントの内容と点数が論理的に一致するように 毎回, 指導をおこなった。グループ学習のため, 学生は評 価をするたびに他の学生の評価方法を聞くことになり, 評 価方法についても相互に学習する環境になったようであ る。中には他の評価に引きずられ, 自分の評価を変えてし まう学生もいたが, 同じ対象であっても評価の観点は違っ ていいことを繰り返し強調した。その結果, 授業に導入し てから 3 回目ぐらいで, 半数の学生は自分なりのコツを掴 んでいる様子が見受けられた。

議論の伝え方の評価指標は, 人前で発表する際に現れる 主な問題を反映したものである。議論の内容の評価指標は, 授業で教えた主張の型に対応している。それぞれの項目を 相互評価することで発表者は自分の課題に気付くことがで きるだけでなく, 評価者自身も他者の発表方法を評価する ことで良い点は学び，改善点は自分のこととして捉えられ るようになっている。相互評価を積極的に取り入れること で, 動機付けが高い学生だけが向上するのではなく, 誰か のスキルの向上が周りの学生にも影響を与えるようにし, クラス全体のレベルが向上するような学習環境をつくっ 
た。これにより，学生間においても，仲間と問題を解決し ながら「協同で学習する」姿勢が養われつつある。学生同 士で評価をしている間には，教員は机間指導をし，質問し やすい雰囲気の中で学習の進度が速い学生および遅い学生 に個別に対応した。

\section{3. 議論教育による認識と行動の変化}

第 2 章で述べた授業を半年間受講し，学生の認識や行動 はどのように変わったのだろうか。本節では議論に対する 認識, 主張の構造および自己認識と行動の変化に関して, 授業開始時（4月）と終了時（7月）に実施した質問紙法と 面接法による調査結果をまとめる。

〈3·1〉 ディベートに対する認識はじめに，授業で 用いたディベートに対する認識の変化を明らかにする。一 般的には学習者の議論に対する苦手意識を克服することは 容易ではなく, 議論教育をおこなったところで学習効果が 上がりにくいことが様々な授業実践で示されている。した がって, 議論に対する認識を肯定的に変化させることが, 技術の習得において重要な課題となる。

そこで，授業前後でディベートについて以下 7 項目につ いて 5 件法で質問した：「問 1 ディベートは得意だ」「問 2 ディベートをするのが好きだ」「問 3 ディベートはきちん と習えば誰でもできる」「問 4 ディベートができるように なりたい」「問 5 ディベートができるようになることは重 要なことだ」「問 6 ディベートは将来役に立つと思う」「問 7 ディベートができたらかっこいいと思う」。結果を図 3 に示す。授業前後の回答の平均值を比較すると, すべての 項目で有意な差が見られた（図 3 参照）：問 $1(t(97)=1.36)$, 問 $2(t(97)=5.39)$, 問 $3(t(97)=2.58)$, 問 $4(t(97)=5.57)$, 問 $5(t(97)=5.88)$, 問 6 $(t(97)=6.63)$, 問 $7(t(97)=4.92)$ 。 各質問項目の平均の差を比較すると, 問 $1: 0.13(S D=.95)$, 問 $2: 0.49(S D=.89)$, 問 $3: 0.29(S D=1.09)$, 問 $4: 0.53(S D=.94)$, 問 $5: 0.52(S D=.87)$, 問 $6: 0.56(S D=.83)$, 問 $7: 0.29(S D=.58)$ で あった。

〈3·2〉 ディベートに対する認識主張の構造＼cjkstart議論教 育による主張の生成過程の変化を明らかにするために，授 業を受講する前にプレテスト（2007 年 4 月）と授業を受講 した後のポストテスト（2007 年 7 月）を実施し，学生の主 張の発話データを分析した。手続きは，テーマを与えてか ら 3 分間の準備後に, 最長 3 分間で意見を発表してもらつ た。発表は IC レコーダーで録音し，すべてのデータは書き 起こされた。死刑制度に関する主張の発話数の平均を図 4 に示す。

結果を比較すると，プレテストでは 1 組 $59.5(S D=39.2)$, 2 組 $65.3(S D=30.3)$ だったのに対して，ポストテストでは 1 組が $152.0(S D=79.9), 2$ 組が $160.5(S D=71.2)$ と，どちらの クラスともに発話数が約 3 倍, 発話数が増えていることが わかる。プレテストとポストテストの発話数が変わらない, あるいは減少した学生の数は皆無であった。この結果から， すべての学生の発話表現に変化が見られ, 学生があるテー

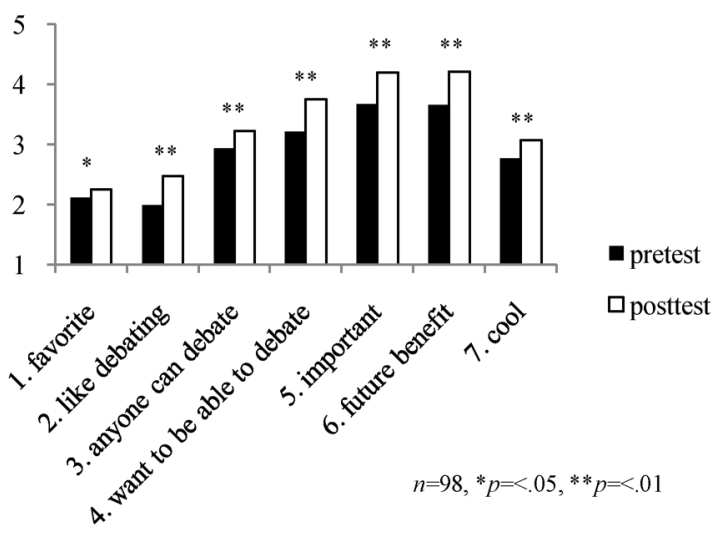

図 3 ディベートに対する認識の変化

Fig. 3. Change of perspectives toward debate.

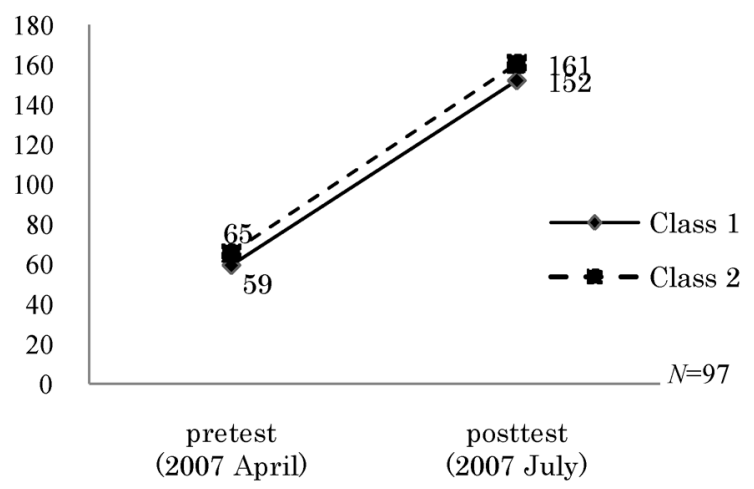

図 4 発話数の変化

Fig. 4. Change of speech words.

マについての意見を述べる際に，他者にわかるように理由 や具体例などの説明を加えていることがわかる。クラスの 違い (1 組と 2 組の 2 水準) $\times$ テスト時期（プレとポストの 2 水準) を独立変数とし, 発話数を従属变数とした分散分析 の結果, クラスの主効果は有意でなかった $(F=.63, d f=$ 1/93, n.s.)。テスト時期の主効果は有意であった $(F=143.19$, $d f=1 / 93, p<.001)$ 。交互作用は有意でなかった $(F=.02, d f=$ $1 / 93$, n.s.)。

次に, 主張の内容を分析するために, 以下に授業を受け る前のプレテストと授業終了時のポストテストの変化の代 表的な一例を示す。テーマは「あなたは喫煙を支持します か」である。

学生 A の事例 :

[プレテスト $]$

反対です。喫煙は自分の身体を悪くするし, 他人にも迷 惑がかかるのであまり好きではありません。（45 字）

[ポストテスト $]$

私は喫煙についてはやや賛成です。なぜなら喫煙をする かしないかは本人の自由だと思うからです。自分の行動 は自分で決める権利がある。だけど非喫煙者の前で吸う のはよくない。いくら吸いたいからといって嫌がってい る人の前で吸うことはできないと思う。だからマナーを 守れる喫煙者に対しては喫煙は賛成だが，マナーを守れ 
ない喫煙者は喫煙してはいけないと思う。以上の理由よ

$$
\text { り，私は喫煙についてはやや賛成です。(193字) }
$$

先に述べたとおり，学生 A の事例でも発話数はポストテ ストではプレテストの 4 倍以上に増えていることがわかる。 プレテストでは最長 3 分間の発表という教示にもかかわら ず，10 秒足らずで発表を終えている。主張を 1 文で終える など，理由について説明しようとしない傾向は約 100 名の 受講生のほとんどに当てはまった。これについて，学生か らは「別にこれ以上説明しょうとは思わない」という消極 的な意見が散見されたが，そもそも「意見をどう伝えてい いのかよくわからない」ことに起因するとも解釈できる。 一方で, ポストテストでは, 立場を支持する理由を詳しく 説明し，結論で締めくくるなど主張が構造化された。授業 では主張の型の定着を図った結果, 「考えるのが速くなっ た」「自分の意見がすぐにうかぶようになった」という意見 が出されており, 基本的な運用能力が育まれていることが 確認できる。

主張の内容を見ると，ポストテストでは「吸うこと自体 は個人の自由である」という新たな視点が取り入れられて いた。確かに身体を悪くすることと他人に迷惑をかけるこ とは喫煙に反対する十分な理由となり得るが，その背後に は喫煙者の吸う権利があり，これを認めるのであれば「他 人に迷惑がかかる」という場合にのみ反対することになる ため「やや賛成」という立場が導かれたと考えられる。ま た，理由の表現方法も異なっていた。プレテストでは「好 き」という個人的な嗜好が判断基準になっている一方で, ポストテストでは「マナーが守れるかどうか」という一般 的に広く受け入れられる理由が挙げられている。このよう に, 主張の構造のみならず, 推論過程における思考の社会 化も学習による変化の 1 つとして認められる。

〈3·3〉自己認識と日常実践授業終了時の質問紙調 査より, 社会に生きる上で必要不可欠な個人内の成長過程 が浮き彫りになった。その内容から，(1)自己認識の発見， (2)素朴認識論の変化, (3)公共性の獲得, (4)対話に開か れた思考，(5)日常生活への浸透，の5つのカテゴリーに分 類できる。以下に回答の抜粋を示す。学生が自身の変化に 敏感になり，説明できるようになったことがうかがえる。

(1) 自己認識の発見

・様々な論題に不安だったが，考えてみると自分にもけ つこう意見があった。

・意見をしっかり持つことが大切だと思うようになった。

(2) 素朴認識論の変化

・他の人の意見の中にその人らしい意見や，自分は考え つかなかったいい意見を発見できるところが面白い。

・違う見方からの意見を聞くと, 少なからず自分の考え が変化する。

(3) 公共性の獲得

・バイト先などで使う会話力が上がった様に思える。敬 語など言葉遣いが身についた。
・人の目を見て話せるようになった。

(4) 対話に開かれた思考

・意見が合わないときは自分の意見を分かりやすく細か く話して理解させるばかりで，相手の意見を打ち消し ていたが，授業を受けてからは相手の意見を積極的に 聞くようになったし「なんで?」が多くなった。

・自分の意見をただ相手に伝えるだけでなく, 自分に対 して逆の意見を述べさせられることで，より多くのパ ターンを想像し, 様々な考え方ができるようになった。

（5）日常生活への浸透

・ニュースを聞くと, 客観的な考えの他に,「その人がな ぜこのようなことをしたか」など考えることが増えた。 ・以前よりも，ニュースを良く見るようになったり，い ろんな出来事に対して, 自分なりの意見を持つように なってきた。さらに, 疑問を持ったことに関して自分 で調べるようにもなってきたと思う。

\section{4. 対話による授業への動機付け}

本コースでは議論について学ぶことを目的としたが，そ れと同時に授業がクラスの交流を深める機会になっていた ことも明らかになった。授業中に意見を交換することで, 新たな友人を見つけることができる。友人ではない同じ学 科の仲間は, 学生にとっての一番近い社会であろう。身近 な社会との対話から社会性が育まれ, 現在, クラスのまと まりが生まれてきている。このためか, 久席や遅刻もこれ までの学年に比べて減少しており, 授業態度について他学 科の教員からも改善されていることが報告されている。

授業を通して多くの学生が何らかの変化を実感している ようであるが, 質問紙の回答より, 家族と暮らしている学 生や, 部活動など何らかの課外活動に参加している学生は, そうでない学生と比較して変化に気付きやすい傾向がある ことがわかった。コミュニケーションについて学んだとこ ろで，それを実践する場面がなければ定着しにくいだろう。 一方で，学んだスキルを発揮する機会に恵まれる程，より 多くの気付きが得られるものと考えられる。また, 同じ変 化であっても，自分で気付く場合と人から気付かされる場 合では異なる側面を捉えていることが多い。このような理 由からも，対話に関する教育は 1 つの授業に閉じるのでは なく, 他の授業や課外活動との連携により更なる効果が期 待される。

\section{5. おわりに}

2007 年度の新入生を対象に, 議論を通して自己理解を深 め, コミュニケーション能力を育成する授業を開講した。 当初, 学生は新しい形式の授業にとまどいを表したが, 最 大限の効果を得るために到達目標に合わせて熟達度に応じ た授業を構成した。その結果，学生のディベートに対する 認識は変化し, 積極的に授業に参加するようになった。議 論そのものについても, 主張構造の発展や複眼的思考方法 の獲得が確認された。半期, 週 1 回という短い期間ではあ 
ったが，学生に適した教育プログラムを開発することで, 一定の効果が得られたと言えるだろう。しかしながら，対 話に関する学習は始まったばかりであるため, 学生が訓練 すべき技術や態度は多く残されている。1 年前期で身に付け たものを 1 年後期, そして専門の授業と関連させ 4 年間で 段階的に発展させるため, 今後, 学生の学習意欲を持続さ せるシステムづくりが肝要である。後継科目および後継年 度の学生の態度や行動の変化についても, 随時, 研究発表 していきたい。

\section{謝 辞}

この研究の一部は, 「福岡工業大学平成 19 年度 教育研究 改善事業」の補助を受けておこなわれています。ここに感 謝の意を表します。

(平成 21 年 4 月 10 日受付, 平成 21 年 6 月 30 日再受付)

\section{文献}

(1) Nippon Keidanren : "Questionnaire result about the graduate recruitment in 2007", http://www.keidanren.or.jp/japanese/policy/2008/003kekka.pdf (2008) (in Japanese)

（社）日本経済団体連合会：2007 年度・新卒者採用に関するアンケ 一下調查結果， http://www.keidanren.or.jp/japanese/policy/2008/ 003kekka.pdf (2008)

(2) M. Nakanao, K. Takahara, and T. Kajiwara : "Instructional design to develop communication ability for students in the electrical engineering majors", IEEJ Trans. FM, Vol.129, No.5, pp.379-385 (2009-5) (in Japanese)

中野美香・高原健爾・梶原寿了：「電気系学生のコミュニケーション 能力の育成を目的とした教育設計」, 電学論 A, 129, 5, pp.379-385 (2009-5)

(3) M. Nakanao, K. Takahara, and T. Kajiwara : "Curriculum development for communication education in the Department of Electrical Engineering of Fukuoka Institute of Technology", The Papers of Technical Meeting on Frontiers in Education, IEE Japan, FIE-07-21, pp.49-54 (2007) (in Japanese)

中野美香・高原健爾・梶原寿了:「福岡工業大学電気工学科における コミュニケーション教育のためのカリキュラム開発」, 電気学会教育 フロンティア研資, FIE-07-21, pp.49-54 (2007)

(4) M. Nakanao, K. Takahara, and T. Kajiwara : "The effect of curriculum development for communication education in Fukuoka Institute of Technology", The Papers of Technical Meeting on Frontiers in Education, IEE Japan, FIE-08-2, pp.7-10 (2008) (in Japanese)

中野美香・高原健爾・梶原寿了:「福岡工業大学電気工学科における コミュニケーション教育の効果」, 電気学会教育フロンティア研資, FIE-08-2, pp.7-10 (2008)

(5) M. Nakanao : "How college students acquire argumentative skills in a community of practice", Jpn Cognitive Sci. Soc., Vol.14, No.3, pp.398-408 (2007) (in Japanese)

中野美香:「実践共同体における大学生の議論スキル獲得過程」, 認 知科学, 14, 3, pp.398-408 (2007)

(6) M. Nakanao : "Explanation and oral expressions", Psychology of Explanation, pp.53-64, Nakanishiya, Tokyo (2007) (in Japanese) 中野美香：「説明と口頭表現」, 説明の心理学, pp.53-64, ナカニシ ヤ出版, 東京 (2007)
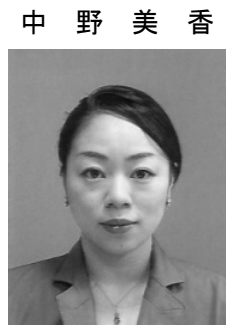

高 原 健 爾

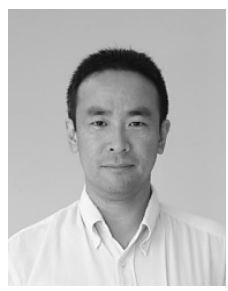

梶 原 寿了

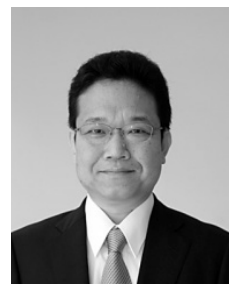

（正員） 1979 年 5 月 19 日生。2006 年 3 月九州 大学大学院比較社会文化学府国際社会文化専 攻博士後期課程修了。同大学大学院人間環境学 研究院学術協力研究員を経て, 2009 年 4 月より 福岡工業大学工学部電気工学科助教。博士 (比 較社会文化)。2006 年日本コミュニケーション 学会論文賞, 2007 年日本認知科学会奨励論文賞 受賞。日本教育心理学会, 国際議論学会会員。

（正員） 1966 年 1 月 11 日生。1997年 3 月東京 医科歯科大学大学院医学系研究科博士課程単 位取得退学。同年 4 月室蘭工業大学工学部電気 電子工学科助手。2005 年 4 月福岡工業大学工学 部電気工学科助教授, 2007 年 4 月より同大学准 教授, 現在に至る。博士 (工学)。

(正員) 1958 年 6 月 17 日生。1981 年 3 月九州 大学工学部電気工学科卒業。1986 年 3 月九州大 学大学院総合理工学研究科エネルギー変換工 学専攻博士後期課程修了。その後, 九州大学大 学院総合理工学研究科助手, 同助教授を経て, 2000 年 4 月福岡工業大学工学部電気工学科教 授。応用物理学会, 電気設備学会会員。 